\title{
UPAYA MENINGKATKAN KEMAMPUAN BERFIKIR LOGIS MATEMATIS MAHASISWA PAPUA DALAM PEMECAHAN MASALAH LUAS DAERAH DI BAWAH KURVA NORMAL
}

\author{
Wiwik Wiyanti ${ }^{1)}$ \\ ${ }^{1}$ Pendidikan Matematika, STKIP Surya \\ wiwik.wiyanti@stkipsurya.ac.id
}

\begin{abstract}
Abstrak
To improve the logical thinking ability of Papuan students, this research was conducted. The material subject of this research is how to solve wide of area under the normal curve. Subject of this research is Papuan students in Class of Statistika Dasar in Mathematics Education major in STKIP Surya Tangerang 2016/2017 academic year. The methods of this research is Qualitative. Data had collected with Test and interview and and to data analysis was using Descriptive Qualitative. The design of this research used Action Research. The result showed that, 1) Students with the high math problem solving skill the area under the normal curve have been able to think coherently, as well as could completion of the work in consecutively and correctly. 2) Students with the math problem solving ability, have been able to think coherently already did the problem in order, but still make errors in final calculation, because careless. 3) Students with low ability in math problem solving, have been able to think coherently already do the problem in order, but there was still a lot of mistake calculations in basic calculations like division of integer, and as well as the final calculations.
\end{abstract}

Kata Kunci: action, logical, thinking, curve, normal

\section{PENDAHULUAN}

Kurikulum program studi pendidikan matematika Sekolah Tinggi Keguruan dan Ilmu Pendidikan Surya (STKIP Surya) salah satunya adalah mata kuliah Statistika Dasar, Statistika Lanjut dan Teori Peluang. Statistika Dasar sendiri adalah mata kuliah yang ditawarkan pada semester 1 dan atau ganjil setiap tahun ajaran di STKIP Surya. Untuk mengambil mata kuliah Teori Peluang, syarat utamanya adalah mahasiswa pernah mengambil mata kuliah statistika dasar dan statistika lanjut, begitu juga syarat mengambil statistika lanjut adalah pernah mengambil mata kuliah statistika dasar. Dalam hal ini, jelas bahwa statistika dasar merupakan mata kuliah dasar yang wajib diambil oleh seluruh mahasiswa tingkat awal program studi matematika STKIP Surya.

Mata kuliah Statistika Dasar di STKIP Surya sendiri mempunyai kompetensi dasar yang harus mahasiswa lalui, salah satunya adalah mahasiswa mampu untuk menyelesaikan permasalahan menentukan luas daerah di bawah kurva normal. Materi tersebut dalam pengerjaannya membutuhkan proses berpikir secara runtut untuk mendapatkan jawaban secara tepat. Sebagai contoh soal sederhana, menentukan nilai z jika luas daerah yang lebih dari nilai $z$ diketahui. Untuk menemukan jawaban soal tersebut dibutuhkan analisa soal serta logika berpikir yang tidak sederhana, keruntutan berpikir, yaitu mampu mengkaitkan sifat peluang, kemudian membutuhkan pemahaman membaca tabel z (Tabel z yang digunakan dalam penelitian ini adalah Weiss, 2012) serta menentukan nilai $z$ yang mempunyai estimasi kesalahan terkecil, baru kemudian mahasiswa mampu menemukan jawaban yang tepat. Hal ini sesuai dengan ciri berpikir logis dalam tulisan Ni'matus (Andriawan dan Budiarto, 2014), karakteristik dari berpikir logis yaitu 1) keruntutan berpikir, yaitu dapat menentukan langkah yang ditempuh secara teratur dalam menyelesaikan permasalahan yang diberikan dari awal perencanaan hingga didapatkan kesimpulan; 2) kemampuan berargumen, yaitu siswa mampu memberikan argumen secara logis sesuai dengan fakta atau 
Halaman $24-30$

informasi yang ada yang terkait langkah perencanaan masalah dan penyelesaian masalah yang ditempuh; dan 3) penarikan kesimpulan, yaitu siswa dapat menarik kesimpulan dari suatu permasalahan yang ada berdasarkan langkah penyelesaian yang telah ditempuh. Arti berpikir logis sendiri yaitu kemampuan siswa untuk menarik kesimpulan yang sah menurut aturan logika dan dapat membuktikan kesimpulan itu benar sesuai dengan pengetahuan-pengetahuan sebelumnya yang diketahui (Siswono, 2008). Selain itu logis dalam kamus besar Bahasa Indonesia adalah sesuai dengan logika, benar menurut penalaran, masuk aka (KBBI, 2017).

Dari analisa data lapangan yang peneliti lakukan selama mengajar statistika dasar, dari tahun 2014 sampai dengan 2015. Nilai kuis materi luas daerah dibawah kurva normal adalah nilai tes harian (kuis) terendah diantara kuis materi lain seperti materi statistika diskriptif, uji homogenitas, uji beda rata-rata. Pada tahun 2015, nilai rata-rata kuis materi luas daerah di bawah kurva normal sebesar 44, 64 dari 14 mahasiswa (2 mahasiswa asal kupang dengan rata-rata nilai adalah 52,5; 5 mahasiswa asal ambon dengan rata-rata nilai 69 dan 7 mahasiswa asal papua sebesar 25), sedangkan untuk kuis materi lain rata-rata kelas sudah mencapai lebih dari 71 . Hasil analisa sementara adalah beberapa mahasiswa mengerjakan soal yang diberikan secara tidak runtut, tidak selesai dalam mengerjakan, salah memberi tanda pertidak samaan, salah membaca tabel, salah menghitung, sampai tidak memberi kesimpulan.

Berdasarkan uraian sebelumnya, maka untuk meminimalisir hasil yang sama di tahuntahun sebelumnya, peneliti berusaha untuk menemukan solusi bagaimana meningkatkan kemampuan berfikir logis matematis mahasiswa untuk materi luas daerah di bawah kurva normal. Dalam penelitian ini mengambil studi kasus mahasiswa papua kelas Statistika Dasar tahun akademik 2016/2017. Hal ini dilakukan karena pertimbangan ciri, karakter subyek yang diteliti adalah secara kemampuan sama dengan subyek tahun sebelumnya. Kemampuan pemecahan masalah dalam penelitian ini adalah kecakapan mahasiswa dalam menyelesaikan soal luas daerah yang diarsir di bawah kurva normal yang diberikan. Kemampuan pemecahan masalah tersebut dilihat dari hasil tes akhir. Kemudian dari skor tes akhir yang diperoleh, mahasiswa dikelompokkan menjadi tiga kelompok dengan kriteria penilaian sesuai standar penilaian STKIP Surya yaitu seperti pada tabel 1 . Yang mana dari penilaian tersebut peneliti menyederhanakan menjadi tiga kategori kemampuan yaitu Tinggi $(A, A-, B+), \quad$ Sedang $\quad(B, B-, C+, C)$ dan Rendah $(C-, D, E)$. Rangkuman kategori kemampuan dalam penelitian ini dapat dilihat pada Tabel 2.

Tabel 1. Standar Penilaian Kemampuan di STKIP Surya

\begin{tabular}{|c|c|c|}
\hline Skor (x) & $\begin{array}{l}\text { Nilai } \\
\text { Huruf }\end{array}$ & $\begin{array}{l}\text { Nilai } \\
\text { Angka }\end{array}$ \\
\hline $90 \leq x \leq 100$ & A & 4 \\
\hline $85 \leq x<90$ & A- & 3,67 \\
\hline $80 \leq x<85$ & $\mathrm{~B}+$ & 3,33 \\
\hline $75 \leq x<80$ & B & 3 \\
\hline $70 \leq x<75$ & B- & 2,67 \\
\hline $65 \leq x<70$ & $\mathrm{C}+$ & 2,33 \\
\hline $60 \leq x<65$ & $\mathrm{C}$ & 2 \\
\hline $55 \leq x<60$ & C- & 1,67 \\
\hline $50 \leq x<55$ & D & 1 \\
\hline $\mathbf{0} \leq \mathrm{x}<\mathbf{5 0}$ & $E$ & 0 \\
\hline
\end{tabular}

Sumber: BAAK STKIP Surya

Tabel 2. Standar Pengelompokan kemampuan dalam Penelitian

\begin{tabular}{|c|c|c|}
\hline \multicolumn{3}{|c|}{ Kemampuan matematis mahasiswa } \\
\hline Tinggi & Sedang & Rendah \\
\hline $80 \leq$ nilai $\leq 100$ & $60 \leq$ nilai $<80$ & $0 \leq$ nilai $<60$ \\
\hline
\end{tabular}

Sumber: BAAK STKIP Surya

Tujuan dari penelitian ini bagaimana peningkatan kemampuan berpikir logis mahasiswa papua yang memiliki kemampuan tinggi, sedang dan rendah dalam memecahkan masalah luas daerah di bawah kurva normal.

\section{METODE PENELITIAN}

Metode penelitian di dalam KBBI, 2017 adalah cara mencari kebenaran dan asas-asas gejala alam, masyarakat, atau kemanusiaan berdasarkan disiplin ilmu yang bersangkutan. Asas dalam KBBI, 2017 adalah dasar (sesuatu yang menjadi tumpuan berpikir atau berpendapat). Dari pengertian tersebut, metode penelitian yang digunakan adalah kualitatif. 
Upaya Meningkatkan Kemampuan Berfikir Logis Matematis Mahasiswa Papua dalam Pemecahan Masalah Luas Daerah di Bawah Kurva Normal

Wiwik Wiyanti

Desain penelitian yang digunakan adalah Action Research. Analisa data pada penelitian adalah secara diskriptif kualitatif.

Penelitian ini dilaksanakan pada semester Gasal tahun akademik 2016/2017 di STKIP Surya. Penelitian dilaksanakan selama 3 hari dalam 3 minggu yaitu tanggal $(13,20$ dan 27 Oktober 2016). Subyek penelitian adalah mahasiswa aktif kelas statistika dasar prodi pendidikan matematika STKIP Surya tahun ajaran 2016/2017. Teknik pemilihan subyek penelitian adalah purposive sample. Penelitian dikatakan berhasil apabila $75 \%$ subyek yang diteliti mendapatkan nilai kuis minimal $C$, yaitu $60 \leq$ nillai kuis $\leq 100$.

Dalam Action Research melibatkan empat tahapan dasar (Fraenkel dan Wallen, 2003) yaitu berupa 1) Identifying the research problem or question, yaitu fokus untuk mengidentifikasi masalah serta mengumpulkan segala informasi yang berhubungan dengan permasalahan, 2) obtaining the the necessary information to answer the problem or question(s), yaitu mengolah segala informasi yang diperoleh dari 1, kemudian membuat perencanaan yang termasuk di dalamnya adalah cara atau metode yang akan digunakan untuk mengatasi permasalahan yang telah diidentifikasi pada tahap 1 kemudian dilakukan tindakan, 3) analyzing and interpreting the information that has been gathered, yaitu tahapan dengan fokus menganalisa dan menafsirkan temuan pada tahap 2, dan 4) developing an action plan of action, yaitu mengembangkan aksi tindakan. Adapun Pelaksanaan penelitian Action Research ini sesuai dengan skema spiral Classroom Action Research adaptasi dari Hopkins (Aqib, 2008). Prosedur pelaksanaan Penelitian Action Research ini sesuai skema dari Taggart (Aqib, 2008).

Pada penelitian ini siklus yang dilalui sebanyak 2 siklus. Teknik pengumpulan data berupa tes kemampuan pemecahan masalah luas daerah di bawah kurva normal, dan wawancara. Tes kemampuan pemecahan masalah luas daerah di bawah kurva normal diberikan kepada subyek penelitian (mahasiswa kelas Statistika Dasar Mat 1 tahun akademik 2016/2017). Setelah data diperoleh peneliti memilih 3 subyek dari masingmasing kelompok kemampuan, kemudian mendiskripsikan kemampuan berpikir logis subyek tersebut. Wawancara dilakukan setelah subyek mengerjakan soal tes kemampuan pemecahan masalah luas daerah di bawah kurva normal yang diberikan. Wawancara dilakukan untuk menggali informasi dari subyek penelitian tentang cara berpikir logis yang muncul ketika mereka mengerjakan soal.

Adapun pedoman pendiskripsian kemampuan berpikir logis subyek penelitian seperti pada tahap pemecahan masalah Polya (Andriawan dan Budiarto, 2014), yaitu 1) Memahami masalah dengan indikator berpikir logis berupa keruntutan yaitu (mahasiswa menyebutkan seluruh atau beberapa informasi dari apa yang ditanyakan pada soal secara tepat, kurang tepat atau tidak tepat), 2) rencana penyelesaian masalah, dengan indikator berpikir logis berupa keruntutan berpikir (mahasiswa dapat, hanya, atau tidak mengungkapkan langkah awal yang akan digunakan dalam penyelesaian masalah) dan kemampuan berargumen (mahasiswa mengungkapkan seluruh, beberapa atau tidak mengungkap langkah-langkah penyelesaian dari awal sampai akhir hingga mendapatkan kesimpulan yang benar, kurang benar atau tidak benar), 3) Melakukan rencana penyelesaian, dengan indikator berpikir logis berupa kemampuan berargumen (mahasiswa dapat menyelesaiakan, seluruh, beberapa atau tidak dapat menyelesaikan langkah pada soal sesuai atau tidak sesuai dengan rencana penyelesaian) dan penarikan kesimpulan (mahasiswa memberikan kesimpulan yang tepat atau tidak tepat pada setiap langkah penyelesaian), 4) Melihat kembali penyelesaian, dengan indikator berpikir logis berupa kemampuan berargumen (mahasiswa mengungkapkan alasan yang logis atau tidak untuk jawaban akhir yang tepat, kurang tepat atau tidak tepat) dan penarikan kesimpulan (mahasiswa mendapat keimpulan di akhir jawaban dengan tepat, kurang tepat atau tidak tepat).

\section{HASIL DAN PEMBAHASAN}

Hasil evaluasi pembelajaran pada siklus 1 dan 2 dirangkum dalam tabel 3. Dari tabel 3 terlihat bahwa penelitian ini terdiri dari dua 
siklus, penjelasan masing-masing sebagai berikut:

\section{Siklus 1.}

Dalam proses pembelajaran pada siklus pertama pengenalan materi dilakukan dengan menjelaskan materi oleh dosen sekaligus peneliti pada penelitian ini. Penjelasan materi dimulai dari membaca tabel kurva normal, hingga menentukan luas daerah di bawah kurva, memberikan latihan soal. Hasil penelitian pada siklus pertama secara data nilai dapat dilihat pada tabel 3. Dari siklus pertama menunjukkan bahwa:

- Kelompok kemampuan matematis rendah sebanyak 15 mahasiswa.

- Kelompok kemampuan matematis sedang sebanyak 1 mahasiswa.

- Kelompok kemampuan matematis tinggi sebanyak 5 mahasiswa.

Intrepretasi: Masih banyak mahasiswa menjawab pertanyaan tidak terstruktur, tidak menuliskan apa yang diketahui, bahkan masih terlihat bingung dalam membaca tabel serta salah dalam menuliskan rumus yang benar. Contoh pekerjaan mahasiswa pada siklus pertama dapat dilihat pada Gambar 2, yang mana masingmasing mewakili dari hasil pekerjaan mahasiswa papua berkemampuan matematis rendah (mahasiswa DB), sedang (mahasiswa YW) dan tinggi (mahasiswa ORT).

Gambar 2. Hasil tes luas kurva di bawah kurva normal siklus 1
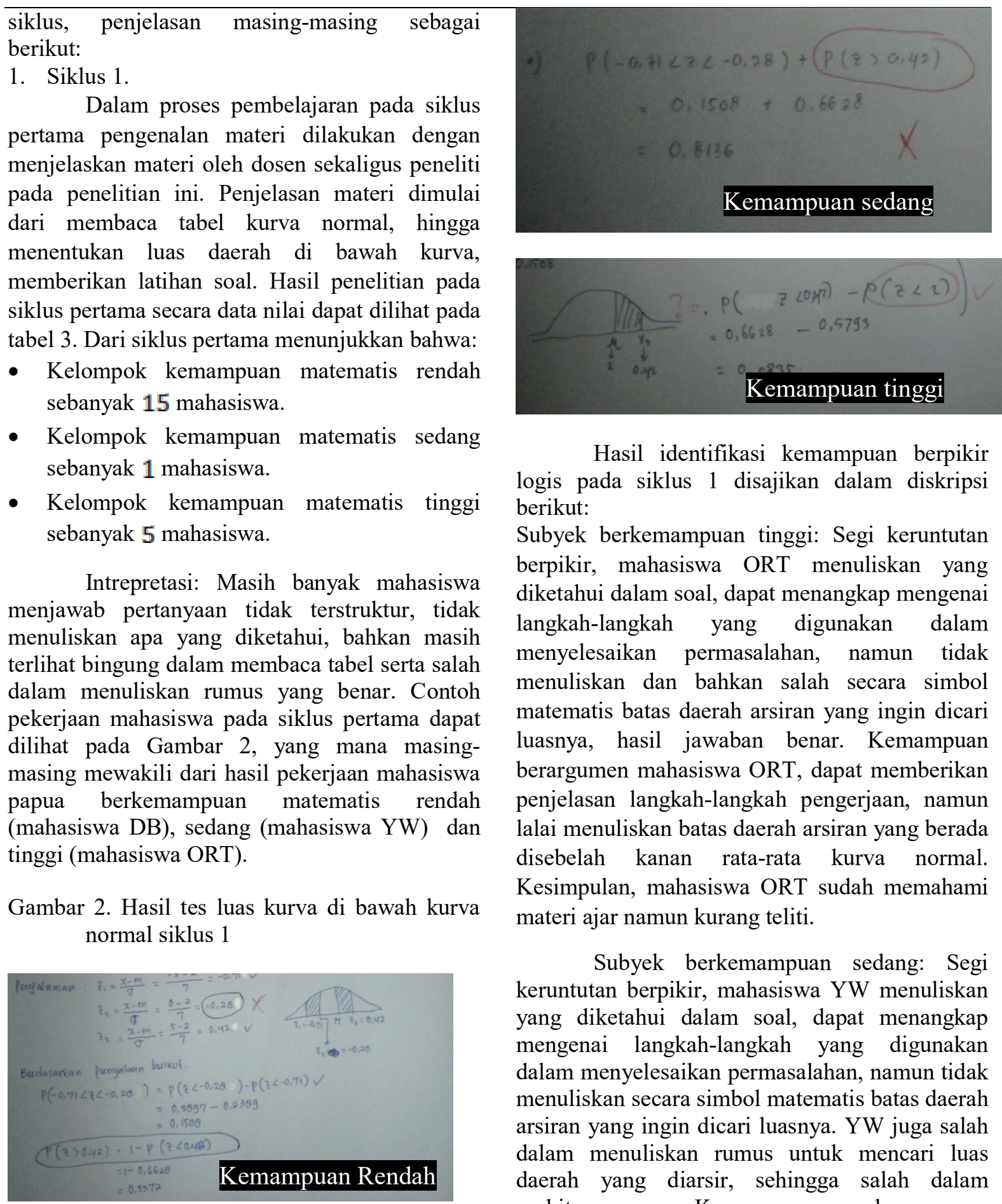

Hasil identifikasi kemampuan berpikir logis pada siklus 1 disajikan dalam diskripsi berikut:

Subyek berkemampuan tinggi: Segi keruntutan berpikir, mahasiswa ORT menuliskan yang diketahui dalam soal, dapat menangkap mengenai langkah-langkah yang digunakan dalam menyelesaikan permasalahan, namun tidak menuliskan dan bahkan salah secara simbol matematis batas daerah arsiran yang ingin dicari luasnya, hasil jawaban benar. Kemampuan berargumen mahasiswa ORT, dapat memberikan penjelasan langkah-langkah pengerjaan, namun lalai menuliskan batas daerah arsiran yang berada disebelah kanan rata-rata kurva normal. Kesimpulan, mahasiswa ORT sudah memahami materi ajar namun kurang teliti.

Subyek berkemampuan sedang: Segi keruntutan berpikir, mahasiswa YW menuliskan yang diketahui dalam soal, dapat menangkap mengenai langkah-langkah yang digunakan dalam menyelesaikan permasalahan, namun tidak menuliskan secara simbol matematis batas daerah arsiran yang ingin dicari luasnya. YW juga salah dalam menuliskan rumus untuk mencari luas daerah yang diarsir, sehingga salah dalam perhitungan. Kemampuan berargumen mahasiswa ORT, dapat memberikan penjelasan langkah-langkah pengerjaan namun belum mengerti bagaimana menuliskan batas daerah arsiran yang berada disebelah kanan rata-rata kurva normal. Kesimpulan, mahasiswa YW 
Upaya Meningkatkan Kemampuan Berfikir Logis Matematis Mahasiswa Papua dalam Pemecahan Masalah Luas Daerah di Bawah Kurva Normal

Wiwik Wiyanti

masih terpaku pada rumus contoh soal yang diberikan pada pengajaran sebelumnya. Ketika soal berubah, bingung bagaimana mengerjakannya.

Subyek berkemampuan rendah: Segi keruntutan berpikir, mahasiswa DB tidak menuliskan yang diketahui dalam soal, dapat menangkap mengenai langkah-langkah yang digunakan dalam menyelesaikan permasalahan, namun tidak menjawab dengan benar untuk perhitungan pembagian, dengan pembilang bilangan bulat negatif, tidak menuliskan simbol matematis dengan benar untuk batas daerah arsiran yang ingin dicari luasnya jika arsiran tersebut berada di sebelah kanan rata-rata dari kurva. Kemampuan berargumen mahasiswa DB, dapat memberikan penjelasan langkah-langkah pengerjaan namun belum mengerti bagaimana menuliskan batas daerah arsiran yang berada disebelah kanan rata-rata kurva normal. Kesimpulan, mahasiswa DB masih terpaku pada rumus contoh soal yang diberikan pada pengajaran sebelumnya. Ketika soal berubah, bingung bagaimana mengerjakannya.

\section{Siklus 2}

Dalam proses pembelajaran siklus kedua, pembelajaran dilakukan dengan membagi kelompok menjadi 5 kelompok belajar. Kelompok 1 adalah kelompok mahasiswa yang nilai tes pada siklus 1 merupakan kelompok berkemampuan sedang sampai tinggi. Kelompok 1 diberikan perkuliahan ulang selama 20 menit, yang kemudian akan disebar ke dalam kelompok 2, 3, 4 dan 5 untuk menjadi tutor sebaya. Selama kelompok 1 mendapatkan kuliah di dalam kelas, kelompok lain diberikan project untuk mengerjakan soal yang harus dikerjakan secara berkelompok di luar kelas, dengan waktu 20 menit, tentunya dengan materi luas daerah di bawah kurva normal. Adapun gambaran kegiatan kelompok 2, 34 dan 5 yang diberikan project soal dan dikerjakan di luar kelas diwakili dalam Gambar 3a, dan kegiatan kelompok 1 yang mendapatkan materi ulang dari dosen (di dalam kelas) diwakili Gambar 3b dan kegiatan tutor sebaya (setelah kelompok 1 disebar ke dalam

kelompok 2, 3, 4 dan 5) dapat dilihat pada Gambar 3c.

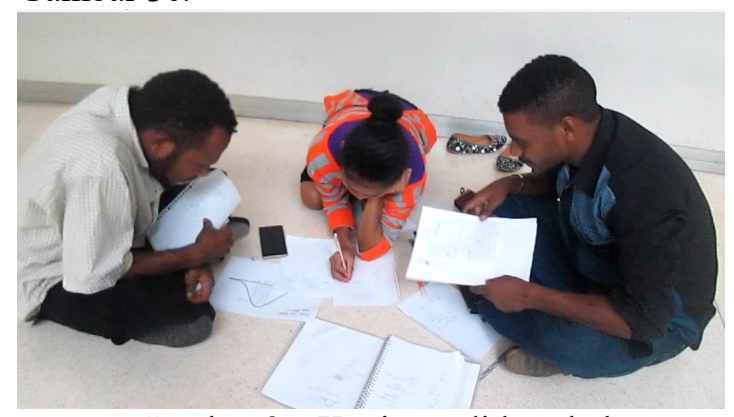

Gambar 3a. Kegiatan di luar kelas

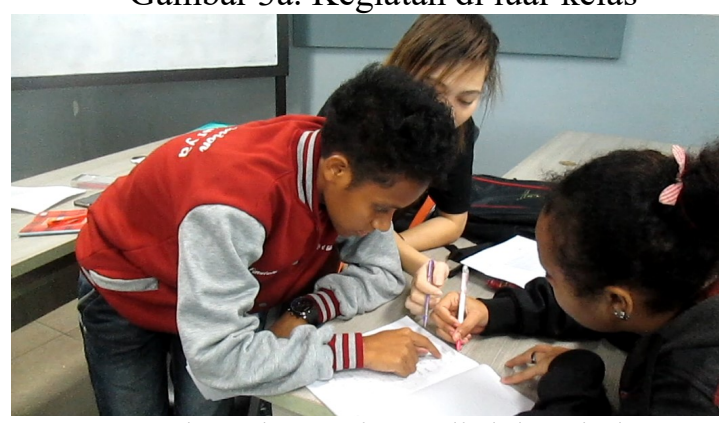

Gambar 3b. Kegiatan di dalam kelas

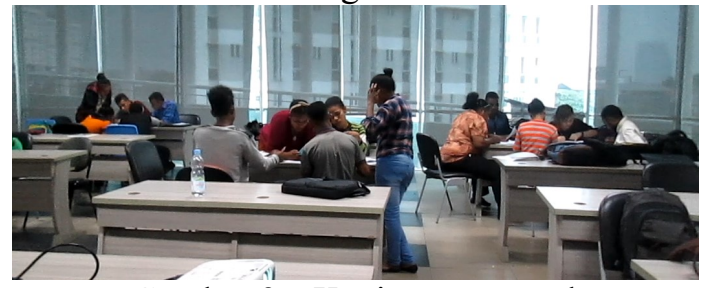

Gambar 3c. Kegiatan tutor sebaya

Hasil penelitian pada siklus kedua secara data nilai dapat dilihat pada tabel 3. Dari proses pembelajarn siklus kedua hasilnya menunjukkan bahwa:

- Kelompok kemampuan matematis rendah sebanyak 6 mahasiswa.

- Kelompok kemampuan matematis sedang sebanyak 3 mahasiswa.

- Kelompok kemampuan matematis tinggi sebanyak 12 mahasiswa.

Intrepretasi: Dari data hasil Tes diperoleh nilai rata-rata tes pada siklus 1 sebesar 45,71 dan siklus 2 sebesar 75, 24. Dari Gambar 4 terlihat tidak ada mahasiswa yang mengalami penurunan nilai, 18 mahasiswa mengalami peningkatan nilai dari postes siklus 1 dan siklus 2, 3 mahasiswa 
Halaman $24-30$

tetap tanpa mengalami perubahan nilai. Karena pada siklus 2 hasil pembelajaran sudah memenuhi harapan, yaitu sesuai indikator berhasilan penelitian ini, yaitu 15 mahasiswa dari 21 mahasiswa (75\% mahasiswa) sudah mencapai nilai $60 \leq$ nilai kuis $\leq 100$, maka penelitian dihentikan.

Yang menarik adalah mahasiswa DB, ON,NW, DT, SS, DD, PW yang asal mulanya dari kelompok Rendah pada siklus 1, menjadi kelompok Tinggi pada siklus 2. Dengan mengambil masing-masing perwakilan kelompok kemampuan, yaitu kelompok kemampuan Tinggi (mahasiswa DB), sedang (mahasiswa MT) dan Rendah (OM), hasil identifikasi kemampuan berpikir logis pada siklus 2 disajikan dalam diskripsi berikut:

Subyek berkemampuan tinggi: Segi keruntutan berpikir, mahasiswa DB menuliskan yang diketahui dalam soal, dapat menangkap mengenai langkah-langkah yang digunakan dalam menyelesaikan permasalahan menulis secara simbol matematis dan perhitungan yang dilakukan sudah benar. Kemampuan berargumen mahasiswa DB, dapat memberikan penjelasan langkah-langkah pengerjaan secara runtut dan sesuai dengan hasil tes tertulisnya. Kesimpulan, karakter kemampuan logis matematis mahasiswa DB adalah dapat menjawab dan mengerjakan soal yang diberikan secara runtut hingga mendapatkan hasil yang benar.

Subyek bekemampuan sedang: Segi keruntutan berpikir mahasiswa MT menuliskan yang diketahui dalam soal, mengerjakan secara runtut sesuai langkah yang digunakan dalam menyelesaikan persoalan, benar melakukan perhitungan sampai akhir, namun masih salah dalam menuliskan simbol matematis. Kemampuan berargumen mahasiswa MT, dapat memberikan penjelasan langkah-langkah pengerjaan secara runtut jauh lebih baik daripada soal tesnya. Kesimpulan, karakter kemampuan logis matematis mahasiswa MT dapat menjawab secara Bahasa namun lemah dalam menuliskan jawaban.
Subyek berkemampuan rendah: Segi keruntutan berpikir, mahasiswa OM menuliskan yang diketahui dalam soal, dapat menangkap mengenai langkah-langkah yang digunakan dalam menyelesaikan permasalahan, namun tidak menghitung dengan benar untuk pembagian bilangan bulat yang mana pembilangnya adalah bilangan negatif, sehingga salah melakukan perhitungan, baik perhitungan dasar berupa pembagian dan luas daerah di bawah. Kemampuan berargumen mahasiswa OM, belum dapat memberikan penjelasan langkah-langkah pengerjaan secara runtut dan belum mampu menjelaskan dengan benar. Kesimpulan, karakter kemampuan logis matematis mahasiswa OM hanya dapat dapat menjawab beberapa langkah namun tidak dapat menjawab langkah sampai akhir dan tidak mendapat hasil akhir yang benar.

Tabel 3. Hasil Tes (Kuis) Luas daerah di bawah kurva normal

\begin{tabular}{|c|l|c|c|c|c|c|}
\hline No & $\begin{array}{c}\text { Nama } \\
\text { Inisial }\end{array}$ & Pretes & $\begin{array}{c}\text { Tes akhir } \\
\text { siklus 1 }\end{array}$ & $\begin{array}{c}\text { Kelompok } \\
\text { Siklus 1 }\end{array}$ & $\begin{array}{c}\text { Tes akhir } \\
\text { siklus 2 }\end{array}$ & $\begin{array}{c}\text { Kelompok } \\
\text { Siklus 2 }\end{array}$ \\
\hline 1 & DB & 0 & 30 & Rendah & 100 & Tinggi \\
\hline 2 & ORT & 0 & 80 & Tinggi & 100 & Tinggi \\
\hline 3 & EF & 0 & 80 & Tinggi & 100 & Tinggi \\
\hline 4 & YW & 0 & 70 & Sedang & 100 & Tinggi \\
\hline 5 & ON & 0 & 50 & Rendah & 100 & Tinggi \\
\hline 6 & WAM & 0 & 50 & Rendah & 70 & Sedang \\
\hline 7 & NW & 0 & 50 & Rendah & 90 & Tinggi \\
\hline 8 & DT & 0 & 50 & Rendah & 90 & Tinggi \\
\hline 9 & SM & 0 & 50 & Rendah & 70 & Sedang \\
\hline 10 & SS & 0 & 20 & Rendah & 80 & Tinggi \\
\hline
\end{tabular}

\begin{tabular}{|c|l|c|c|c|c|c|}
\hline No & $\begin{array}{c}\text { Nama } \\
\text { Inisial }\end{array}$ & Tes awal & $\begin{array}{c}\text { Tes akhir } \\
\text { siklus 1 }\end{array}$ & $\begin{array}{c}\text { Kelompok } \\
\text { Siklus 1 }\end{array}$ & $\begin{array}{c}\text { Tes akhir } \\
\text { siklus 2 }\end{array}$ & $\begin{array}{c}\text { Kelompok } \\
\text { Siklus 2 }\end{array}$ \\
\hline 11 & RA & 0 & 90 & Tinggi & 100 & Tinggi \\
\hline 12 & MT & 0 & 20 & Rendah & 70 & Sedang \\
\hline 13 & DD & 0 & 30 & Rendah & 80 & Tinggi \\
\hline 14 & PW & 0 & 50 & Rendah & 100 & Tinggi \\
\hline 15 & MA & 0 & 100 & Tinggi & 100 & Tinggi \\
\hline 16 & MY & 0 & 0 & Rendah & 30 & Rendah \\
\hline 17 & Al & 0 & 10 & Rendah & 30 & Rendah \\
\hline 18 & ID & 0 & 50 & Rendah & 50 & Rendah \\
\hline 19 & OM & 0 & 10 & Rendah & 20 & Rendah \\
\hline 20 & YP & 0 & 20 & Rendah & 50 & Rendah \\
\hline 21 & AP & 0 & 50 & Rendah & 50 & Rendah \\
\hline
\end{tabular}

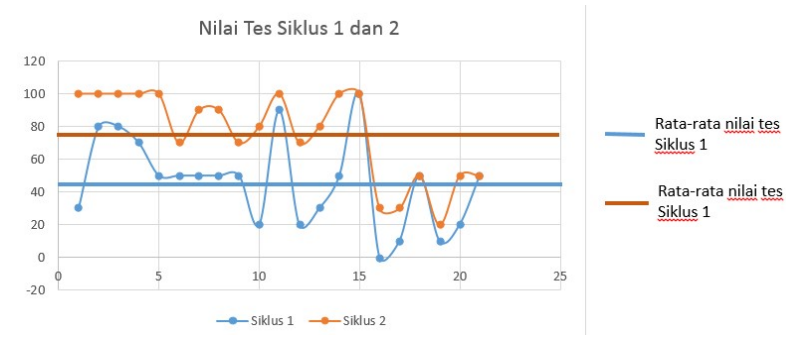


Upaya Meningkatkan Kemampuan Berfikir Logis Matematis Mahasiswa Papua dalam Pemecahan Masalah Luas Daerah di Bawah Kurva Normal

Wiwik Wiyanti

Gambar 4. Grafik nilai Tes (Kuis) luas daerah di bawah kurva normal

\section{KESIMPULAN}

diperoleh simpulan bahwa peningkatan kemampuan berpikir logis mahasiswa papua yang memiliki kemampuan tinggi, sedang dan rendah dalam memecahkan masalah luas daerah di bawah kurva normal adalah sebagai berikut:

1. Kelompok berkemampuan tinggi dalam pemecahan masalah luas daerah di bawah kurva normal dari segi keruntutan berpikir, mampu menuliskan yang diketahui dalam soal, dapat menangkap mengenai langkahlangkah yang digunakan dalam menyelesaikan permasalahan menulis dengan benar simbol matematis dan benar dalam perhitungan yang dilakukan. Bahkan secara kemampuan argumen, dapat memberikan penjelasan langkah-langkah pengerjaan secara runtut dan sesuai dengan hasil tes tertulis.

2. Kelompok bekemampuan sedang dalam pemecahan masalah luas daerah di bawah kurva normal dari segi keruntutan berpikir, mampu menuliskan yang diketahui dalam soal, mengerjakan secara runtut sesuai langkah yang digunakan dalam menyelesaikan persoalan, benar melakukan perhitungan sampai akhir, namun masih salah dalam menuliskan simbol matematis. Kemampuan berargumen pada kelompok sedang, dapat memberikan penjelasan langkah-langkah pengerjaan secara runtut jauh lebih baik daripada soal tesnya.

3. Kelompok berkemampuan rendah dalam pemecahan masalah luas daerah di bawah kurva normal dari segi keruntutan berpikir, sudah menuliskan apa yang diketahui dalam soal, dapat menangkap mengenai langkahlangkah yang digunakan dalam menyelesaikan permasalahan, namun tidak menghitung dengan benar untuk perhitungan dasar seperti pembagian bilangan bulat dalam kasus pembagian bilangan bulat yang mana pembilangnya adalah bilangan negatif, sehingga salah melakukan perhitungan, baik perhitungan dasar berupa pembagian dan luas daerah di bawah. Kemampuan berargumen kelompok ini, belum dapat memberikan penjelasan langkah-langkah pengerjaan secara runtut dan belum mampu menjelaskan dengan benar.

\section{REFERENSI}

Andriawan, B. dan Budiarto, M. T. 2014. "Identifikasi Kemampuan Berpikir Logis dalam Pemecahan Masalah Matematika pada Siswa Kelas VIII-1 SMP NEGERI 2 Sidoarjo". MATH Edunesa Jurnal Ilmiah Pendidikan Matematika Volume 3 No 2 Tahun 2014. Surabaya.

Aqib, Z. (2008). PENELITIAN TINDAKAN KELAS: Untuk Guru. YRAMA WIDYA. Bandung

Fraenkel, J. R. dan Wallen, N. E. 2003. How To sDesign AND Evaluate Research IN Education FIFTH EDITION. McGrawHill Company. Inc. New York.

https://kbbi.web.id/logis (diakses 30 Desember 2017)

Siswono, T. Y. E. 2008. "Model Pembelajaran Matematika Berbasis Pengajuan dan Pemecahan Masalah untuk Meningkatkan Kemampuan Berpikir Kreatif". Unesa University Press: ISBN 978-979-028-097-7. Surabaya.

Weiss, N.A. 2012. "Elementary Statistics $8^{\text {th }}$ Edition". Pearson Education, Inc. 